DOI: $10.54631 /$ VS.2021.S-122-123

\title{
NEW VIETNAM THROUGH THE EYES OF ITS PEOPLE
}

\author{
Jérémy Jammes
}

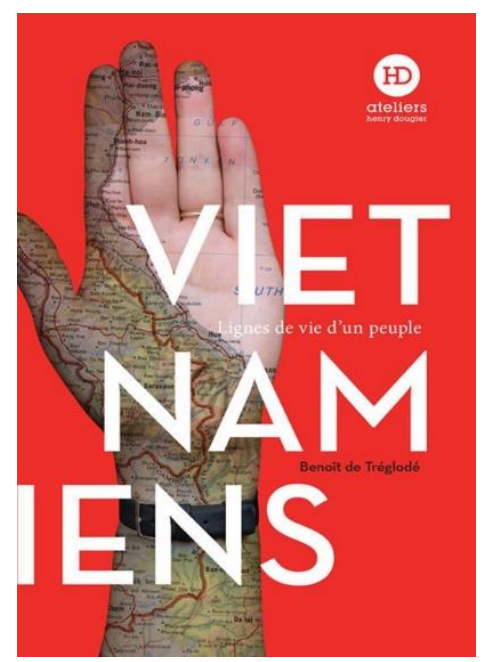

\author{
Benoît de Tréglodé. Vietnamiens. Lignes de vie d'un peuple \\ [Vietnamese. Lifelines of a People]. Paris: Ateliers Henri-Dougier, \\ 2021. 154 p. ISBN-13: 979-1031202426
}

Abstract. The review is given for the book "Vietnamese. Lifelines of a People" by Benoît de Tréglodé. 26 interviews with Vietnamese men and women of different ages and places of residence, professions and social status create a portrait of the Vietnamese people, a picture of their current life, character, beliefs and culture.

Keywords: Vietnam, the Vietnamese, autobiographical portraits, history, Vietnam War, traditional culture, Đổi mới policy.

Benoît de Tréglodé's "Vietnamiens. Lignes de vie d'un peuple (Vietnamese. Lifelines of a people)" is a part of a series published by Ateliers Henri-Dougier, "Lignes de vie d'un peuple (Lifelines of a people)". Briefly, this collection focuses on a 'people' who are part of a nation (Cambodians, Mexicans, etc.) or who have a clear sense of identity (the Scots, Frenchspeaking Canadians, etc.). A journalist or researcher is then invited to share his or her encounters and conversations with selected members of this particular people. Each book aims to "showcase the vitality and inventiveness of a people, highlighting what is singular and universal, familiar and strange about them". Accordingly, this book does not pretend to be targeted at a specialist audience, but rather is oriented towards the general public.

In the case of Vietnamiens, it contains a series of autobiographical portraits: twenty-six Vietnamese men and women of all ages, ranging from urban to rural, from lowlanders to highlanders, from atheistic to Buddhist or Catholic, from various social positions, from close to far away from political power. These narratives were compiled from interviews, which are intended to reveal the little and big stories that constitute the plural density of the people and of Vietnam's contemporary history. The collector of these interviews, historian Benoît de Tréglodé, is currently director of research and head of the Africa - Asia - Middle East domain at the Strategic Research Institute of the École Militaire (IRSEM). The author is therefore well placed to identify "the Vietnamese" who best embody the spirit of the times and the ongoing changes in Vietnamese society. The resulting book is a 154-page, non-jargon style book that flows smoothly. The table of contents includes a letter of intent from the author, a historical introduction, six thematic chapters and a series of appendices (key figures and dates for the country, a short list of Vietnamese authors, artists and intellectuals, and few references). It is divided into the following chapters: "A heterogeneous territory shaped by history", "War and Peace", "A new relationship with the world", "Traditional culture and creativity", "Pleasures and everyday life", and "Exile and nostalgia for the country". Each chapter consists of the 
transcription of 4 or 5 interviews, which respond, in a brief and personal way, to questions on the life trajectory of the interviewees (deputy, nurse, Catholic father, singer, filmmaker, seamstress, LGBT activist, former member of the intelligence service, researchers, etc.), living in the North, the Centre, the South of the country or living in exile.

This patchwork of narratives enables the reader to look beyond the commonplace, to abandon the nostalgic discourse of the Indochinese colonial era but rather to meditate on the evolution of a country and its citizens following the Vietnam War. Focusing on the smallest units of the Vietnamese people, the individual, the citizen, subsequently leads to more general, even fundamental questions, such as: "Are we now writing about the war in Vietnam in the same way we wrote about it in the 1960s and 1970s?" (p. 47), "What are young Vietnamese writers writing about?" (p. 49), "How has Vietnamese identity been altered by all these geopolitical changes engendered by Đổi mới?” (p. 68), “Are arranged marriages still numerous?" (p. 81), "Can we make a film of everything in Vietnam today?" (p. 113), "To what extent is Vietnam's policy of economic openness a success? In your opinion, what are the limits of this opening up?" (p. 134), etc.

These contemporary narratives are captured in the manner of photographic snapshots, accepting both the limit and the strength, the uniqueness and the potential for generalization, of these narratives. To use the photographic metaphor, it is noteworthy that French colonization and the Vietnam War constitute rarely the historical 'backdrop' of the main 'photographed' (interviewed) subject. This historical horizon seems to be very distant in the concerns of the interviewees. On the other hand, three periods return regularly in the words of the interviewees as referring moments in their lives: the time right after independence (1975), the so-called "subsidy period", characterized by a peace gained at the price of human losses, economic restrictions, and sacrifices; the Đổi mới policy (1986), "to change in order to make something new", a sort of Vietnamese-style perestroika which series of reforms would eventually bring hope and lift the frenetic spirit of the population and of the market, impacting political, economic, and social decisions at varying degrees of the society; the fall of the Soviet Union and the subsequent necessity to rethink the country's international postures, leading directly to the end of the American embargo in 1994, to the country's admission as a member of ASEAN in 1995, to the opening up of its tourism sector, to its registration with the OECD, etc.

The various encounters selected by the author are by no means representative of the entire population, but invite the targeted reader - the well-informed tourist, the entrepreneur, the journalist, the diplomat - to revisit the monopolistic discourse offered by the Communist Party, which provides "a simplified mirror, [...] an ideal interpretation of history transformed into a unifying narrative [as well as] a moral vision of the country's future" (p. 10). To go even further in this critical and decentred approach regarding the official discourse, it would be desirable to repeat this type of collection and transcription of life stories of "Vietnamese citizens" who are often relegated to the margins of society ("ethnic minorities" Cham, Hmong, Jarai, Khmer Krom, Tay, etc.; "religious minorities" like Hòa Hảo Buddhism, Cao Đài religion, Protestant Evangelical Protestantism and others) who do not appear in this volume although their active contribution to the history of Vietnam, as well as to the ethnic and ideological diversity of the country.

\section{Aвmop:}

Jérémy Jammes, Professor of Anthropology and Asian Studies, Sciences Po Lyon. Email: jeremy.jammes@sciencespo-lyon.fr 